\title{
Trace minerals profile of blood serum and estrual mucus in repeat breeder Kankrej cows
}

\author{
L C Modi ${ }^{1}$, B N Suthar ${ }^{2}$, C F Chaudhari ${ }^{1}$, N F Chaudhari ${ }^{1}$, H C Nakhashi ${ }^{2}$ and Falguni Modi ${ }^{3}$ \\ 1. Department of Animal Reproduction, Gynaecology \& Obstetrics, College of Veterinary Science \& AH, Navsari \\ Agricultural University, Navsari- 396450 (Gujarat), India; 2. Department of Animal Reproduction, Gynaecology \& \\ Obstetrics, College of Veterinary Science \& AH, Sardarkrushinagar Dantiwada Agricultural University, S. K. Nagar-385506 \\ (Gujarat), India; 3. Department of Vety. Pharmacology \& Toxicology, College of Veterinary Science \& AH, Navsari \\ Agricultural University, Navsari- 396450 (Gujarat), India. \\ Corresponding author: L C Modi, email: lalitcmodi4364@gmail.com
}

Received: 11-06-2012, Accepted: 07-07-2012, Published online: 27-12-2012

How to cite this article: Modi LC, Suthar BN, Chaudhari CF, Chaudhari NF, Nakhashi HC and Modi F (2013) Trace minerals profile of blood serum and estrual mucus in repeat breeder Kankrej cows, Vet World 6(3): 143-146, doi: 10.5455/vetworld. 2013.143-146

\begin{abstract}
Aim: The study was carried out with an idea to ascertain involvement of trace minerals in failure of conception in Knakrej cow.

Materials and Methods: The animals under study were comprised of 10 normal (Group-I) and 20 repeat breeder (Group-II) Kankrej cows. Blood and estrual mucus of each repeat breeding and normally cycling cows were collected aseptically before breeding. The cervical mucus was diluted with triple glass distilled water at the rate of $1: 3$ using vertex machine. Serum and diluted mucus was used for the trace minerals estimation.

Results: The values observed for copper, iron, zinc and manganese in blood serum of normal and repeat breeding animals was $2.27 \pm 0.05$ vs $0.87 \pm 0.02,1.41 \pm 0.02$ vs $0.65 \pm 0.01,1.94 \pm 0.01$ vs $1.78 \pm 0.02$ and $0.43 \pm 0.02$ vs $0.18 \pm 0.01 \mathrm{ppm}$, respectively and in estrual mucus it was $1.37 \pm 0.10$ vs $0.44 \pm 0.06,0.74 \pm 0.07$ vs $0.33 \pm 0.05,1.47 \pm 0.10$ vs $0.82 \pm 0.06$ and $0.29 \pm 0.04$ vs $0.23 \pm 0.03 \mathrm{ppm}$, respectively. All the values in blood serum and estrual mucus were significantly ( $<0.01)$ higher in normal than repeat breeder cows except manganese in estrual mucus, which was non significantly higher in normal as compared to repeat breeder Kankrej cows.
\end{abstract}

Conclusion: All trace minerals was higher in blood serum of Group I animals as compared to Group II. In estrual mucus except manganese, all trace minerals was higher in normal cows than repeat breeder.

Keywords: blood serum, estrual Mucus, repeat breeder, trace minerals

\section{Introduction}

An important source of economic loss in dairy herds is the presence of repeat breeder cows that fail to conceive after three or more inseminations without detectable abnormalities in their genital tracts and with apparently normal estrus cycles [1]. Any deviation or prolongation in the breeding rhythm results in a progressive economic loss due to widening of the dry period, reduced calvings, lactations during the life span of the animal, increasing culling and replacement cost, wasting semen and insemination cost and loosing genetic gain through increased generation interval $[2,3]$. It is an unexplained infertility problem because many cows repeat for a temporary period and than conceive spontaneously. Trace elements may function as cofactors, as activators of enzymes or stabilizers of secondary molecular structure [4]. Trace minerals involved in carbohydrate, protein and nucleic acid metabolism due to this, any changes in its level may alter the production of reproductive and other hormones. Its improper level may affect embryonic development, post-partum recovery activities and over all fertility of animal [5]. In spite of all advances the repeat breeding a form of sub fertility that affects 10$15 \%$ of cows has still remained the most economically important cattle infertility problem [6]. There is very close relationship between the reproductive tract secretions, ovarian function and hormonal activity. Estrual mucus plays a vital role in fertility and breeding efficiency of a cow by providing an immediate nourishing, protective environment to spermatozoa deposited in female genital tract. Rupde et al. [7] studied the reproduction in relation to trace elements viz iron, copper, manganese and zinc and breeding efficiency in regular and repeat breeder cows and registered their significance for reproduction.

The study was carried out with an idea to ascertain involvement of trace minerals in failure of conception in Knakrej cow.

\section{Materials and Methods}

Animals: The study was approved by the committee framed for the research by the university authority and conducted on Kankrej cows maintained at Livestock Research Station, Sardarkrushinagar Dantiwada Agricultural University, Sardarkrushinagar during the period of June 2006 to May 2007. The animals under study were comprised of 10 normal (Group-I) and 20 repeat breeder (Group-II) Kankrej cows. The group I cows were normal fertile which conceived at $1^{\text {st }}$ or $2^{\text {nd }}$ breeding whereas, the group II consist of such cows which conceived after more than two breeding with 
Table-1. Overall average ( $\mathrm{X} \pm \mathrm{S} . \mathrm{E}$.) of Copper, Iron, Zinc, Manganese concentration in blood serum of Group I and Group II Kankrej cows during oestrus.

\begin{tabular}{lllll}
\hline Sr. No. & Estimation & Group I(N=10) & Group II(N=20) & Pooled value(N=30) \\
\hline 1. & Copper (ppm) & $2.27 \pm 0.05^{* *}$ & $0.87 \pm 0.02$ & $1.33 \pm 0.12$ \\
2. & Iron (ppm) & $1.41 \pm 0.02^{* *}$ & $0.65 \pm 0.01$ & $143.74 \pm 0.07$ \\
3. & Zinc (ppm) & $1.94 \pm 0.01^{* *}$ & $1.78 \pm 0.02$ & $1.83 \pm 0.02$ \\
4. & Manganese (ppm) & $0.43 \pm 0.02^{* *}$ & $0.18 \pm 0.01$ & $0.27 \pm 0.02$ \\
\hline
\end{tabular}

** $\mathrm{P}<0.01$, Group I = Normal breeder, Group II = Repeat breeder

Table-2. Overall average (X+S.E.) of Copper, Iron, Zinc, Manganese concentration in estrual mucus of Group I and Group II Kankrej cows during oestrus.

\begin{tabular}{llllc}
\hline Sr. No. & Estimation & Group I(N=10) & Group II(N=20) & Pooled value(N=30) \\
\hline 1. & Copper (ppm) & $1.37 \pm 0.10^{* *}$ & $0.44 \pm 0.06$ & $0.75 \pm 0.10$ \\
2. & Iron (ppm) & $0.74 \pm 0.07^{\star *}$ & $0.33 \pm 0.05$ & $0.47 \pm 0.05$ \\
3. & Zinc (ppm) & $1.47 \pm 0.10^{* *}$ & $0.82 \pm 0.06$ & $1.04 \pm 0.08$ \\
4. & Manganese (ppm) & $0.29 \pm 0.04$ & $0.23 \pm 0.03$ & $0.25 \pm 0.02$ \\
\hline
\end{tabular}

** $\mathrm{P}<0.01$, Group I = Normal breeder, Group II = Repeat breeder

fertile semen. These cows were also ruled out for any apparent cause of conception failure.

Collection of sample: Blood samples of each repeat breeding and normally cycling cows was collected before artificial insemination; serum was separated. The mucus samples were collected aseptically before breeding by aspiration using a sterilized glass pipette $(10 \mathrm{ml})$, whose pointed end was connected to a syringe with rubber junction. The glass pipette was followed per rectally to pass through the cervix or near the vaginal fold. The cervical mucus was diluted with triple glass distilled water at the rate of $1: 3$ using vertex machine. The diluted mucus was used for the trace minerals estimation.

Trace minerals estimation: The trace elements viz, copper, iron, manganese and zinc were studied by atomic absorption spectrophotometer (Model AA 646, Shimadzu make) method as described by Oser [8]. The serum and diluted cervical mucus was digested using the tri-acid mixture and final volume was made $10 \mathrm{ml}$ by adding double glass distilled water for the estimation of trace elements at the Regional Research Station, Sardarkrushinagar Dantiwada Agricultural University, Sardarkrushinagar.

Statistical analysis: The comparison of trace elements concentration in serum and estrual mucus of Group I and Group II cow was performed by a well known statistical method of two sample " $t$ " test [9].

\section{Results and Discussion}

The serum and estrual mucus copper value was significantly $(\mathrm{p}<0.01)$ higher in Group I as compared to Group II (Table-1 \& 2). The higher serum copper value is in agreement with Ahmed et al. [10], Das et al. [11] and Ceylan et al. [12]. However, Balakrishna and Balagopal [13] and Dutta et al. [14] observed apparently higher serum level of copper in repeat breeding cows. Shukla and Sharma [15], reported non-significant alteration in the concentration of copper between the uterine fluid of normal and repeat breeding crossbred cows whereas Vadodaria and Prabhu [4] reported significantly lower value of this element in estrual mucus of conceived buffaloes when compared to nonconceived group.

Copper has significant role in maintaining the optimum fertility as it behaves in a regular way as an indicator for FSH, LH and estrogen activity [16]. Plasma copper concentrations of aborting cows were significantly lower than recently calved cows so, it seems that copper deficiency has close relationship with abortion in cattle [17] Copper along with Cobalt deficiency delayed onset of puberty, repeat breeding, low conception, early embryonic mortality and increased incidence of retention of placenta [5].

The value of serum and estrual mucus iron was significantly $(p<0.01)$ higher in Group I when compared to Group II cows (Table-1 \& 2). The higher serum iron value is in consonance with Ahmed et al. [10], Das et al. [11] and Ceylan et al. [12]. Similarly, Prasad and Rao [18], Singh and Pant [19] and Rupde et al. [20], reported non-significant higher serum iron concentration in normal cows as compared to repeat breeder cows. The findings of Eltohamy et al. [21] and Das et al. [22] were contradicted to the findings of the present study. Similar observations of estrual mucus iron was recorded by Vadodaria and Prabhu [4] in conceived $(2.39 \pm 0.60 \mathrm{mg} \%)$ and non-conceived (1.65 $\pm 0.62 \mathrm{mg} \%$ ) groups of Mehsani buffaloes.

Iron functions in transport of oxygen to tissues maintenance of oxidative enzyme system and is concerned with ferritin formation [23]. However lower level of serum iron results in anemia, which in turn affects reproduction adversely in the form of repeat breeding, requiring increased number of insemination per conception and occasionally leading to abortion [5]. Lower level of serum iron plays a significant role in causing failure of conception and embryonic death due to change in molarity of the oviductal fluid in repeat breeding [24].

The significantly $(\mathrm{p}<0.01)$ higher value of serum and estrual mucus zinc in Group I cows when compared to Group II (Table1 \& 2). Ahmed et al. [10], Das et al. [11] and Ceylan et al. [12] also opined that the 
serum zinc concentration was higher in normal as compared to repeat breeder. However, Chandraker et al. [25] reported that serum zinc level was nonsignificantly higher $(5.57 \pm 1.67 \mathrm{mg} / \mathrm{ml})$ in repeat breeder cows than in normal fertile cows $(4.55 \pm 0.83$ $\mathrm{mg} / \mathrm{ml}$ ). Vadodaria and Prabhu [4] reported the value of zinc was significantly $(\mathrm{p}<0.01)$ higher in cervical mucus of conceived $(3.358 \pm 0.61 \mathrm{mg} \%)$ as compared to non-conceived $(2.60 \pm 0.66 \mathrm{mg} \%)$ Mehsani buffaloes. However, Shukla and Sharma [15] reported nonsignificant alteration in the concentration of zinc between the uterine fluid of normal $(0.73 \pm 0.17 \mathrm{mg} \%)$ and repeat breeding crossbred cows $(0.65 \pm 0.12 \mathrm{mg} \%)$.

Optimum level of zinc is essential to maintain the activity of FSH and LH [11] and there by facilitates normal reproductive performance. Moreover, prostaglandin binds zinc and facilitates its transports. Zinc finger proteins play an integral role in regulating gene expression, consequently impacting a wide variety of body functions including cell division, growth, hormone production, metabolism, appetite control, and immune function [26]. Zinc deficiency may lead to reduction in GnRH secretion by hypothalamus and eventually lead to decrease levels of luteinizing hormone and follicular stimulating hormone and arrest of ovulation [27]. Zinc deficiencies have been associated with abortion, fetal mummification, lower birth wt and prolonged labour as Zn plays important role in uterine lining [5].

The value of manganese in serum was significantly ( $p<0.01)$ higher in Group I as compared to Group II cows (Table-1). Similarly Rupde et al [7] and Dutta et al [14] reported significant higher manganese value in normal cows as compared to repeat breeder crossbred cows. However, Das et al [22] documented non significant difference between the normal cyclic and repeat breeder crossbred cows.

Estrual mucus manganese in Group I and Group II cows was $0.29 \pm 0.04$ and $0.23 \pm 0.03 \mathrm{ppm}$, respectively (Table-2). The manganese value was non-significantly higher in Group I as compared to Group II. However, Vadodaria and Prabhu [4] reported the value of manganese in oestrus cervical mucus of conceived group was $0.90 \pm 0.69 \mathrm{mg} \%$ and in non-conceived group $0.11 \pm 0.02 \mathrm{mg} \%$ the value was significantly higher in conceived as compared to non-conceived Mehsani buffaloes.

The precise pathway of specific manganese involvement in reproduction process remains unknown, although evidences suggested that manganese plays a critical role in the activity of certain endocrine organs [28]. Manganese deficiency has been reported to reduce first service conception rates and reduce fertility in ruminants [29].

\section{Conclusion}

All the serum and Estrual mucus trace minerals viz. iron, copper, manganese and zinc were significantly $(\mathrm{p}<0.01)$ higher in normal breeder as compared to repeat breeder cows except manganese in cervical mucus, which was non-significantly higher in normal breeder as compared to repeat breeder Kankrej cows.

\section{Authors' contribution}

LCM, BNS and HCN implemented the study design, carried out the experiment and analysed the data. LCM, BNS, HCN, CFC, NFC and FM drafted and revised the manuscript. All authors read and approved the final manuscript.

\section{Acknowledgements}

The authors are highly thankful to the staff of Livestock Research Station and Department of Animal Reproduction, Gynaecology and Obstetrics; College of Veterinary Science and Animal Husbandry, Sardar krushinagar Dantiwada Agricultural University, Sardarkrushinagar for providing necessary help for the study.

\section{Competing interests}

Authors declare that they have no competing interests.

\section{References}

1. Katagiri S. (2011). A new approach to repeat breeding in cows: treatments targeting the endometrial growth factorcytokine network. Thai J Vet Med Suppl. 2011.41: 51-53.

2. El-Khadrawy, H. H., Ahmed, W. M., Emtenan and Hanafi M. (2011). Observations on repeat breeding in farm animals with emphasis on its control. Journal of Reproduction and Fertility. 2(1):01-07.

3. Osman Ergene. (2012). Progesterone concentrations and pregnancy rates of repeat breeder cows following post insemination PRID and GnRH treatments. Turk. J. Vet. Anim. Sci. 36(3): 283-288.

4. Vadodaria,V.P. and Prabhu,G.A. (1990). Effect of level of tress elements in estrual cervical mucus on fertility in Mehsana buffaloes. Indian J. Anim. Reprod., 11:130-135.

5. Kumar, Sudhir., Pandey A. K.,Razzaque, W.A.A. and Dwivedi, D. K. (2011). Importance of micro minerals in reproductive performance of livestock. Vet. World, 4(5): 230233.

6. Mouli Krishna K., Seshagiri Rao A., Venugopal NAidu K. and Mutha Rao M. (2006). Uterine luminal protein and serum progesterone profile in repeat breeding cows. Indian Vet. J. 83: 284-287.

7. Rupde, N. D., Rode, A. M., Sarode, D. B., Zade, N. N., Jagtap, D. G. and Kaikini, A. S. (1993). Serum biochemical profiles in repeat breeders. Indian J. Anim. Repro., 14 : 7981.

8. Oser, B.L. (1979), Hawks Physiological Chemistry. $14^{\text {th }}$ Edn., Mc Grew Hill Books Co. Bombay.

9. Snedecor, G.W and Cochran, W.G. (1994). Stastical methods. $8^{\text {th }}$ edn. Oxford and IBH publishing co., New Delhi, India.

10. Ahmed, W.M.; Zaabal, M.M. and Abdel Hameed, A.R. (2010). Relationship between ovarian activity and blood lead concentration in cows and buffaloes with emphases on gene frequencies of hemoglobin. Glob. J. Biotechnol. Biochem., 5(1): $1-5$.

11. Das, J. M.; Dutta, P; Deka, K. C.; Biswas, R. K.; Sarmah, B. C. and Dhali, A. (2009): Comparative study on serum macro and micro mineral profiles during oestrus in repeat breeding crossbred cattle with impaired and normal ovulation. Livestock Research for rural development, 21 (5).

12. Ceylan, A.; Serin,I.; Aksit, H. and Seyrek, K. (2008). Concentrations of some elements in dairy cows with reproductive disorders .Bull. Vet. Inst. Pulawy, 52:109-112.

13. Balakrishna, V. and Balagopal, R. (1994). Serum calcium, 
phosphorus, magnesium, copper and zinc level in regular breeding buffaloes. Indian Vet. J., 71:23.

14. Dutta, M., Baruah, S. N., Sarmah, B. C. and Baishya, N. (2002). Comparative study of certain micro-minerals in the serum of normal and repeat breeding crossbred cows. Indian Vet. J., 79:794-796.

15. Shukla, S. P. and Sharma, R. D. (2006). Studies on biochemical changes in the uterine fluid of repeat breeding crossbred cows. Indian J. Anim. Reprod., 27(1):21-22.

16. Desai, M.C., Thakkar, T. P. Amin Darshone, R. and Janakiramon, J. (1982). A note on serum copper and iron in surti buffaloes in relation to reproduction and gonadotropins. Indian J. Anim. Sci., 52:443-444.

17. Sakhaee, E. and Kazeminia, S. (2011). Relationship between liver and blood plasma copper level and abortion in cattle. Comparative Clinical Pathology, 20 (5): 467-469.

18. Prasad, K. S. N. and Rao, S. V. N. (1997). Blood mineral profile of anoestrus and repeat breeder crossbred cows- a field study. Indian J. Anim. Nutr., 14(2):135-137.

19. Sing, M. and Pant, H. C. (1998). Blood biochemical profile of normal and repeat breeder cows in Himachal Pradesh. Indian J. Anim. Reprod., 19(2): 156-157

20. Rupde, N.D., Rode, A.M., Sarode, D.B., Zade, M.N., Jagtap, D.G. and Kaikine,A.S. (1998). Serum biochemical profile in repeat breeders. Indian J. Anim. Reprod. 19:79-81.

21. Eltohamy, M. M., mYunis, M., Salem, H. A., Azouz, Affaf, Shawky, H. and Farahat, A. A. (1989). Role of some macro and micro elements in indicing repeat breeding in buffaloes. Indian J. Anim. Sci., 59:1406-1409.

22. Das, S., Bandopadhya, S.K., Basu, S. Ghosh, B.B. and Dattagupta, R. (2002). Blood mineral profile of normal cyclic and repeat breeder cross bred cows under rural condition. Ind. J. Anim. Reprod. 23(2): 167-169.

23. Khillare, K. P., Sahatpure, S. K., Vanlalpeka, K., Bombatkar, R. S. and Tijare, G. S. (2007). Trace minerals and reproduction in animals. Intas Polivet , 8(2):308-314.

24. Jain, G. C. (1994). Mineral profiles during anoestrum and repeat breeding in bovines. Inter. J. Anim. Sci., 9:241-245.

25. Chandrakar, D., Tiwari, R. P., Awasthi, M. K. and Tiwari, S. P. (2002). Serum trace elements level in repeat breeder crossbred cows. Indian Vet. Med. J., 26:243-244.

26. Gressley T. F. (2009). Proceedings of the 7th Annual MidAtlantic Nutrition Conference at Zimmermann, N.G., ed., University of Maryland.

27. Kaswan, S. and Bedwal, R. S. (1995). Light and electron microscopic changes in the ovary of zinc deficient BALB/c mice. Indian J. Exp. Biol.33(7):469.

28. Randhawa, S. S. and Randhawa, C. S. (1995). Proceeding of the summer institute of recent advances in animal Reproduction and Gynaecology, held at P.A.U, Ludhiana, July 25 to August 13, 1994.

29. Lehmkuhler J. (2010). Applied Reproductive Strategies Conference Proceedings August 5th \& 6th,Nashville, TN.

$* * * * * * * *$ 